\title{
Positive but also negative effects of ethnic diversity in schools on educational performance? An empirical test using PISA data
}

Citation for published version (APA):

Dronkers, J., \& van der Velden, R. K. W. (2013). Positive but also negative effects of ethnic diversity in schools on educational performance? An empirical test using PISA data. In M. Windzio (Ed.), Integration and Inequality in Educational Institutions (pp. 71-98). Springer. https://doi.org/10.1007/978-94-007-61193_4

Document status and date:

Published: 01/01/2013

DOI:

10.1007/978-94-007-6119-3 4

Document Version:

Publisher's PDF, also known as Version of record

Document license:

Taverne

Please check the document version of this publication:

- A submitted manuscript is the version of the article upon submission and before peer-review. There can be important differences between the submitted version and the official published version of record.

People interested in the research are advised to contact the author for the final version of the publication, or visit the DOI to the publisher's website.

- The final author version and the galley proof are versions of the publication after peer review.

- The final published version features the final layout of the paper including the volume, issue and page numbers.

Link to publication

\footnotetext{
General rights rights.

- You may freely distribute the URL identifying the publication in the public portal. please follow below link for the End User Agreement:

www.umlib.nl/taverne-license

Take down policy

If you believe that this document breaches copyright please contact us at:

repository@maastrichtuniversity.nl

providing details and we will investigate your claim.
}

Copyright and moral rights for the publications made accessible in the public portal are retained by the authors and/or other copyright owners and it is a condition of accessing publications that users recognise and abide by the legal requirements associated with these

- Users may download and print one copy of any publication from the public portal for the purpose of private study or research.

- You may not further distribute the material or use it for any profit-making activity or commercial gain

If the publication is distributed under the terms of Article $25 \mathrm{fa}$ of the Dutch Copyright Act, indicated by the "Taverne" license above, 


\title{
Chapter 4 \\ Positive but also Negative Effects of Ethnic Diversity in Schools on Educational Performance? An Empirical Test Using PISA Data
}

\author{
Jaap Dronkers and Rolf van der Velden
}

\subsection{Average/Share and Diversity of School Populations as Different Concepts}

This chapter focuses on two characteristics of educational institutions: sociocultural average or share of school populations on the one hand and sociocultural diversity on the other. Average/share and diversity are important characteristics of students' learning contexts and are thus supposed to influence their educational performance.

The sociocultural average of the school population is the single most influential school characteristic in all Organization for Economic Cooperation and Development (OECD) countries, more important than either a shortage of qualified teachers or class size (Scheerens and Bosker 1997). In the context of this chapter, "sociocultural average of a school population" is defined as the average social status of the students' parents. The higher the average social status of these parents, the better the students perform compared with similar students in schools in which the parents have a lower average social status. Sometimes, researchers also use the share of high- or low-status parents instead of the average. Both have the same meaning. Since the Coleman report (1966), this has been one of the controversial insights in

\footnotetext{
This chapter is an improved version of the inaugural lecture of the first author as professor of international comparative research on educational performance and social inequality at Maastricht University, held on June 17, 2010 (Dronkers, 2010b). The improvements are based on the introduction of a more valid measurement of schools and curriculum (Dronkers et al. 2011).
}

\author{
J. Dronkers $(\bowtie) \cdot$ R. van der Velden \\ Research Centre for Education and the Labour Market (ROA), \\ Maastricht University, 616, NL-6200 MD Maastricht, The Netherlands \\ e-mail: j.dronkers@maastrichtuniversity.nl \\ R. van der Velden \\ e-mail: r.vandervelden@maastrichtuniversity.nl
}


education science. Note, however, that the effects of a school's sociocultural average are smaller than the effects of an individual parent's social status on the performance of the student.

The sociocultural diversity of a school population concerns the variety of students in that school in terms of sociocultural status. The sociocultural diversity of a school is great if the parents of its students include parents from both high, middle and low social classes. A school with parents from only either high, middle or low social classes is classified as a school with a slight diversity.

Diversity and average/share are related concepts, but they are conceptually quite different. Schools can be low in diversity (e.g., with only high- or loweducated parents), but their averages may differ greatly (the former has a high average educational level, the latter a low average educational level). The opposite is also possible. Schools in which the students' parents are of the same average sociocultural status may differ considerably as to diversity: one school may have only parents with the same social class, while another school has parents from quite diverse social classes, but the average of those levels may still correspond to that of the first school.

The concepts of diversity and average/share of schools are often confused, not only in everyday conversation but also in policy documents. In addition, almost all studies on the effects of school populations (Driessen 2007; van Ewijk and Sleegers 2010) restrict themselves to measuring the average/share, while the diversity of the school populations is not addressed separately. ${ }^{1}$ However, it is necessary here to make a clear distinction between average/share and diversity, because they are intrinsically different concepts, even if they are strongly related in real situations. In this chapter, we will measure the average/share and diversity separately, and determine their individual effects on educational performance.

\subsection{Ethnic and Sociocultural Dimensions as Distinctive Phenomena}

We have already used the example of sociocultural average and diversity, in which the parents' social status is used to measure both. Another dimension whereby school populations differ is the country of origin of the students' parents, whichfor the sake of brevity-we will here refer to as ethnic share and diversity. These two dimensions are also often confused, and in this chapter, we will measure both dimensions separately. The sociocultural dimension is based a composite measure that indicates parent's social status. ${ }^{2}$ For the ethnic dimension, we distinguish

\footnotetext{
1 An exception is Van Houtte and Stevens (2009), but they used interethnic friendships and feeling at home in school as dependent variables.

2 The parental social class is measured using the index of economic, social, and cultural status of the parents (ESCS). This is a composite index in the PISA dataset based on the occupational
} 
students with an immigrant background based on their country of origin. A series of cross-national studies, starting with Tubergen (2005), has shown that it is necessary to look simultaneously at the country of origin and the destination country of immigrants and their children. ${ }^{3}$ Failing to do so leads to distorted results, with regard to the interpretation of school characteristics (such as average/ share and diversity) and educational systems, because the nature of the immigration process, results in immigrants being unevenly distributed across schools and educational systems.

\subsection{The Research Questions}

In this chapter, we will try to answer two research questions:

1. Does greater ethnic and sociocultural diversity of schools promote the educational performance of students with an immigrant background, while hampering the performance of native students, if we take into account the ethnic and sociocultural average/share of the school population?

2. To what extent does the degree of differentiation in secondary education influence the effects of ethnic and sociocultural diversity, and the ethnic and sociocultural average/share of school populations?

We will try to test these two questions empirically using data from the PISA 2006 survey. This large-scale cross-national dataset allows us to compare the language skills of 15-year-old students in OECD countries. The advantage of using international PISA data for this analysis is that a large group of countries is involved, which prevents conclusions based on some idiosyncratic groups of immigrants in particular destination countries.

\subsection{Mechanisms that may Create a Positive Effect of Diversity}

Greater diversity of school populations means that diverse schools have more students whose capabilities and potential differ from one another. The following mechanisms could therefore create a positive effect of diversity on individual educational performances: (1) in more diverse schools, good students may help weaker fellow students, either by giving actual help or by setting an example;

(Footnote 2 continued)

status of the parents measured with the ISEI scale (Ganzeboom et al. 1992), the educational level of the parents measured with the ISCED classification (UNESCO 2006), and the presence of any material or cultural resources at the students' homes.

3 Examples of such studies with both the country of origin and the destination country include Levels et al. (2008), Dronkers and Fleischmann (2010), De Heus and Dronkers (forthcoming). 
(2) in more diverse schools, weaker students have a greater chance of encountering a challenging curriculum, because the teachers teach such subject matter to the better students; (3) more capable students in more diverse schools also learn better themselves, because they explain the subject matter to weaker students.

Accordingly, if these mechanisms are powerful enough, promoting ethnic and sociocultural diversity is a policy instrument for increasing the quality of schools, and we found clear evidence of the ways educational institutions' social structures can have positive effects on educational performance. However, the institutional effects of diversity can also be negative.

\subsection{Mechanisms that may Cause a Negative Diversity Effect}

The mechanisms that are supposed to cause a negative diversity effect include: (1) a more homogeneous student population increases the possibility that teachers specialize in teaching their specific students, thus increasing school effectiveness; (2) In a more homogeneous population, less time needs to be spent on bridging ethnic and sociocultural differences between students, leaving more time for teaching and learning, and hence school effectiveness is higher; (3) in more homogeneous schools, the mutual trust among students, parents, and teachers is assumed to be higher, resulting in greater involvement of students, parents, and teachers, and hence greater effectiveness of such schools. ${ }^{4}$

The limitations of PISA data do not allow measuring all these mechanisms separately, so for the purpose of this chapter, we are only able to measure the sum total of positive and negative mechanisms.

\subsection{Mechanisms that may Cause the Average Effect of School Populations}

The sociocultural average of student populations affects educational performance through five mechanisms (for a detailed discussion of these mechanisms, see Dronkers 2010a): (1) the curriculum level at which teachers in a school with a particular student population are able to teach; (2) the benchmark with which students assess their own performance, given the level of their fellow students; (3) the amount or real teaching time for teachers and real learning time for students, which

\footnotetext{
4 Putnam (2007) has shown that greater ethnic diversity in neighborhoods may lead to a lower general feeling of trust in neighborhood and neighbors. Lancee and Dronkers (2011) found the same negative relationship between ethnic neighborhood diversity and trust for the Netherlands. It seems reasonable to assume that the same phenomenon occurs in schools as well.
} 
decreases by the loss of time that needs to be spent on repetition of insufficiently understood subject matter or addressing topics other than teaching; (4) the total volume of financial, cultural, and social resources that the parents of the students from specific populations may provide in order to allow the teaching and learning process to run as well as possible; (5) the average quality of teachers at schools.

Partly because of the limitations of PISA data, we cannot measure all these mechanisms separately for this chapter, but the total outcome of these mechanisms can be measured. Only the last two mechanisms (resources and teacher quality) to some extent can be separately included in the analysis.

\subsection{Educational Systems and Diversity of School Populations}

The degree of stratification in secondary education may have an influence on the effects of diversity and average/share of school populations, because the more differentiated an educational system is, the greater the chance of large differences between schools, and hence school populations, and low differences within schools (and hence low diversity). Not taking into account the educational system within which schools operate therefore leads to misspecification of school populations' effects (Dunne 2010). In addition, both Heus and Dronkers (2010) and Fossati (2010) suggest that stratification of educational systems among students with an immigrant background has a different effect than among native students. Immigrants from different countries of origin are also unequally distributed across destination countries, and hence across educational systems.

\subsection{Prior Research}

Strangely enough, no empirical studies have been done that simultaneously measure the effects of average/share and diversity of school populations on educational performance. Most studies restrict themselves to measuring the effects of the average/share of school populations (see Driessen 2007) and, depending on the quality of the measurement of ethnic and sociocultural average/shares (van Ewijk and Sleegers 2010), find significant effects, even though-as usual-these are small compared with individual effects of social and ethnic background (Scheerens and Bosker 1997). Westerbeek's dissertation (1999) comes closest to the approach used here, but her data for the Netherlands were too restricted to be able to analyze average/share and diversity simultaneously. 


\subsection{Data}

For this chapter, we have used the 2006 version of the PISA. Since 2000, 15 -year-old students living in a large number of OECD member-states have been taking this test every three years. The purpose of this test is to map competencies in the fields of mathematics, physics, and reading at the end of the compulsory education period (at the age of 16 or 17 in most Western countries). Although the focus of PISA 2006 is on physics, the test also measured the students' reading skills (OECD 2007), and it is these reading skills that have been used for this chapter. ${ }^{5}$ The PISA data for each participating country constitute a representative sample of the schools that teach 15-year-old students. Each school that has been selected tests a sample of all 15-year-olds, irrespective of their level or grade. In addition to educational performance, PISA also supplies information on a large number of characteristics pertaining to individual background and school. The school principals provide details on a variety of school characteristics, such as student-teacher ratio, teacher shortages, and the location of the school. In the student questionnaires, students are asked for information on such things as the sociocultural status of their parents, the availability of resources at home, the language spoken at home, and the country in which their parents were born. Considering that the information on the country of origin of both parents is crucial for the two research questions, we can only include countries that provide sufficient specific information on these countries of birth. Although no fewer than 57 countries took part in PISA 2006, only the following 15 Western countries provided this information: Australia, Austria, Belgium, Denmark, Finland, Germany, Greece, Latvia, Liechtenstein, Luxembourg, New Zealand, Norway, Portugal, Scotland, and Switzerland. ${ }^{6}$ In order to determine students' country of origin, several decision rules have been used based on their own birth country and the birth countries of their parents. Next to the students' country of birth, we identified his/her immigrant status, derived from the birth countries of both parents. Students of whom at least one of the parents was born in a country outside the country of the test were identified as immigrants.

PISA data contain two cross-national indicators of the track the students are attending. The student is asked whether he or she is currently enrolled in a certain track of a certain level. This was later recoded in the international format, distinguishing between general and vocational tracks on the one hand, and between lower and higher tracks on the other (see Dronkers et al 2011).

\footnotetext{
5 The results for mathematics and physics basically are not different, but in the case of language skills, they are more pronounced for students with an immigrant background (for obvious reasons).

6 The relevant question was not asked in a similar way in all countries. The question was to indicate a limited number of countries of birth, based on the main immigrant groups in the country concerned (e.g., in the German questionnaires, possible countries of birth were: Russia, the former Yugoslavia, Greece, Italy, Poland, and Turkey, while the Scottish questionnaire listed the options as China, India, the Middle East, Africa, the Caribbean, and Europe).
} 
Schools are the sampling unit in the PISA survey. These schools, however, often contain both general and vocational education, and both levels within secondary education. The school level therefore reflects more the administrative unit of the educational institution, while the combined two-track characteristics reflect more the daily reality of the teaching and learning environment, as well as the social interactions between students and teachers. This daily life unit is a better indicator of the actual school environment of teaching and learning than is the administrative unit. We call this the track-within-school level and compute this level per country for each student by combining his or her school identification number, the kind of track he or she is following (vocational or general), and the track level (lower or higher). Dronkers et al. (2011) offer a detailed description of the result of this redefinition of school environment from an administrative unit into the daily life unit of teaching and learning. In order to avoid extreme results for combinations with few cases, we deleted all combinations of school identification number, vocational or general education, and the track level, which had less than six students (natives and immigrants) per school.

The analysis was based on 8,521 immigrant students from 35 different countries of origin, living in 15 Western destination countries, attending 1,756 schools, 1,960 track-within-schools, and all 72,329 native students in these 15 Western countries, attending 2,861 schools and 3,311 track-within-schools. We refer to previous publications for a detailed description of the data and the coding of all variables (Heus and Dronkers 2010; Dronkers et al. 2011).

\subsection{Variables}

The variables used are shown in Table 4.1, separated for native students and students with an immigrant background. The variables were coded similarly for both categories of students, with the immigrant characteristics (such as the country of origin) being irrelevant for native students.

\subsubsection{Dependent Variable: Linguistic Performance}

The dependent variable in this study is linguistic performance. To measure linguistic skills accurately would make the test too long to be feasible. Hence, we created a large number of very similar but shorter tests. Because such different tests can never offer exactly the same degree of difficulty, Item Response Modeling (IRM) was used to achieve comparable results between students who took different tests. In this analysis, we averaged the five plausible values that were obtained from the IRM and used that result as the dependent variable. The linguistic skills scores were standardized for the OECD countries using an average of 500 and a 
standard deviation of 100 . The mean scores of the students with an immigrant background per country of origin and destination are given in Table 4.2, along with the mean scores of the native student per test country (last row, Table 4.2).

Table 4.1 Maxima, minima, means, and standard deviations, separated for both native students and students with a migrant background

\begin{tabular}{|c|c|c|c|c|c|c|c|c|}
\hline & \multicolumn{4}{|c|}{ Native students } & \multicolumn{4}{|c|}{ Immigrant students } \\
\hline & Min. & Max. & Mean & $\begin{array}{l}\text { Std. } \\
\text { deviation }\end{array}$ & Min. & Max. & Mean & $\begin{array}{l}\text { Std. } \\
\text { deviation }\end{array}$ \\
\hline Science & 107.74 & 825.65 & 517.47 & 91.43 & 130.30 & 841.04 & 468.65 & 103.36 \\
\hline Math & 81.55 & 804.63 & 516.27 & 87.44 & 154.92 & 790.07 & 479.81 & 94.65 \\
\hline Reading & 81.02 & 800.16 & 505.76 & 91.75 & 67.34 & 775.21 & 463.00 & 102.81 \\
\hline Average ESCS school & -2.19 & 1.69 & 0.15 & 0.50 & -2.07 & 1.64 & 0.03 & 0.50 \\
\hline Diversity ESCS & 0.00 & 0.80 & 0.65 & 0.08 & 0.00 & 0.79 & 0.66 & 0.07 \\
\hline Diversity ethnic & 0.00 & 0.84 & 0.13 & 0.16 & 0.03 & 0.84 & 0.41 & 0.20 \\
\hline$\%$ Western OECD & 0.00 & 91.80 & 3.61 & 7.63 & 0.00 & 100.00 & 14.75 & 18.62 \\
\hline \% Eastern Europe & 0.00 & 66.67 & 2.29 & 5.70 & 0.00 & 66.67 & 7.99 & 12.81 \\
\hline$\%$ Islamic countries & 0.00 & 92.31 & 1.20 & 4.25 & 0.00 & 92.31 & 5.97 & 13.46 \\
\hline$\%$ non-Islamic Asia & 0.00 & 83.33 & 0.77 & 3.35 & 0.00 & 87.50 & 2.53 & 8.11 \\
\hline$\%$ Sub-Saharan Africa & 0.00 & 33.33 & 0.28 & 1.38 & 0.00 & 33.33 & 1.13 & 3.10 \\
\hline $\begin{array}{l}\text { Vocational orientation of } \\
\text { school }\end{array}$ & 0.00 & 1.00 & 0.07 & 0.25 & 0.00 & 1.00 & 0.08 & 0.27 \\
\hline Level of track & 0.00 & 1.00 & 0.39 & 0.49 & 0.00 & 1.00 & 0.34 & 0.48 \\
\hline School size & 9.00 & 4,468 & 682.67 & 447.17 & 23 & 4,468 & 845.77 & 629.17 \\
\hline Teacher-student ratio & 0.89 & 36.59 & 11.79 & 3.74 & 0.89 & 36.59 & 11.69 & 3.94 \\
\hline Teacher shortage & -1.06 & 3.62 & 0.09 & 0.95 & -1.06 & 3.62 & 0.29 & 0.98 \\
\hline School in rural area & 0.00 & 1.00 & 0.39 & 0.49 & 0.00 & 1.00 & 0.29 & 0.46 \\
\hline School in city & 0.00 & 1.00 & 0.26 & 0.44 & 0.00 & 1.00 & 0.37 & 0.48 \\
\hline Female & 0.00 & 1.00 & 0.50 & 0.50 & 0.00 & 1.00 & 0.50 & 0.50 \\
\hline ECSC & -4.39 & 3.35 & 0.18 & 0.89 & -4.44 & 2.97 & -0.23 & 1.02 \\
\hline Immigrant. first generation & & & & & 0.00 & 1.00 & 0.46 & 0.50 \\
\hline $\begin{array}{l}\text { Immigrant. second } \\
\text { generation }\end{array}$ & & & & & 0.00 & 1.00 & 0.50 & 0.50 \\
\hline Mixed marriage & & & & & 0.00 & 1.00 & 0.06 & 0.23 \\
\hline Eastern Europe & & & & & 0.00 & 1.00 & 0.27 & 0.45 \\
\hline Western OECD & & & & & 0.00 & 1.00 & 0.45 & 0.50 \\
\hline Islamic country & & & & & 0.00 & 1.00 & 0.16 & 0.37 \\
\hline Non-Islamic Asia & & & & & 0.00 & 1.00 & 0.09 & 0.29 \\
\hline Sub-Saharan Africa & & & & & 0.00 & 1.00 & 0.04 & 0.18 \\
\hline Language of destination & & & & & 0.00 & 1.00 & 0.50 & 0.50 \\
\hline $\begin{array}{l}\text { Grade (destination country } \\
\text { centered) }\end{array}$ & -2.00 & 3.00 & 0.5924 & 0.80 & -2.00 & 3.00 & 0.37 & 0.87 \\
\hline Strongly stratified system & 0.00 & 1.00 & 0.3493 & 0.48 & 0.00 & 1.00 & 0.56 & 0.50 \\
\hline Moderately stratified system & 0.00 & 1.00 & 0.2237 & 0.42 & 0.00 & 1.00 & 0.14 & 0.35 \\
\hline Valid $N$ & 72,329 & & & & 8,521 & & & \\
\hline
\end{tabular}

Source PISA 2006; own computations 


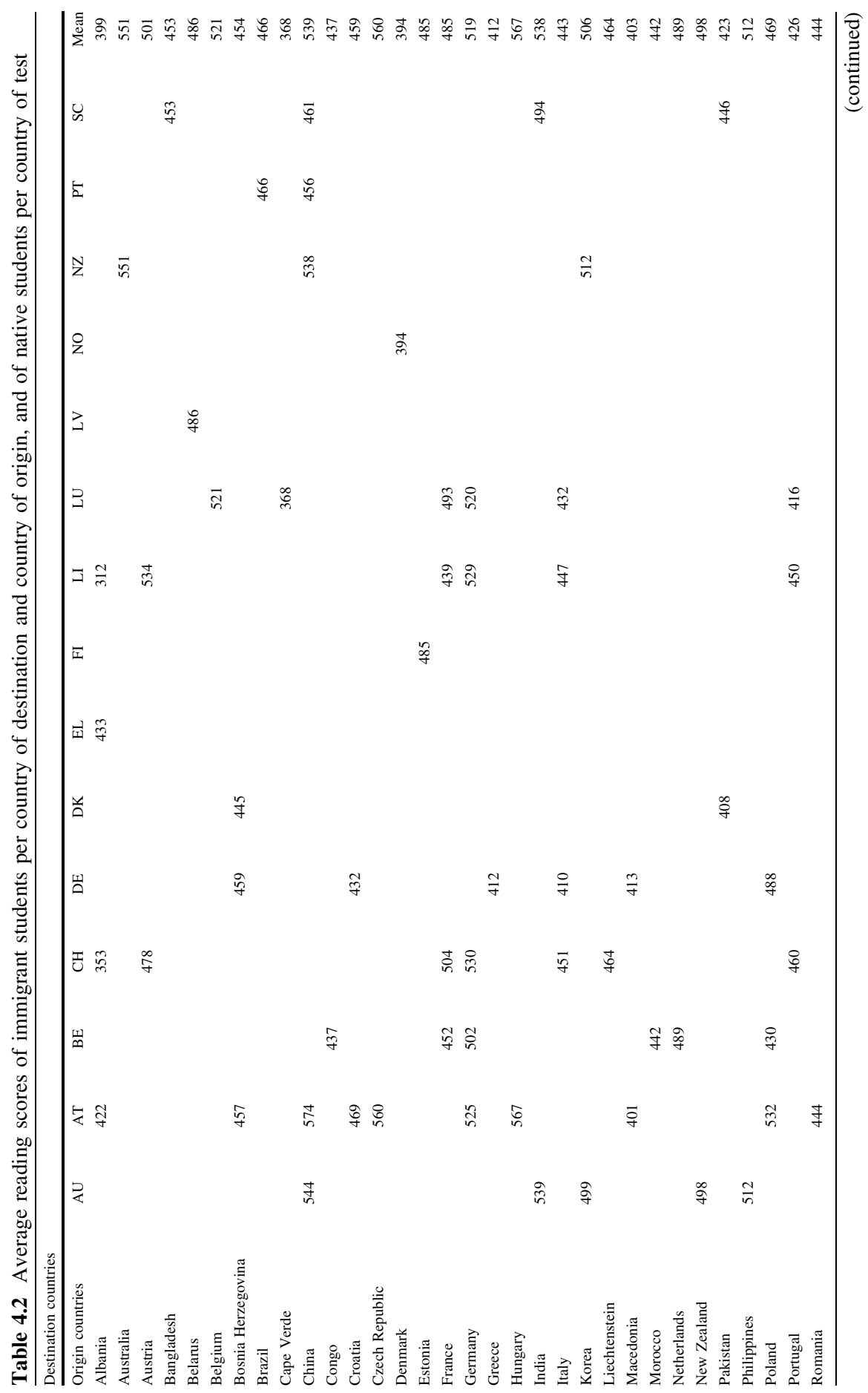




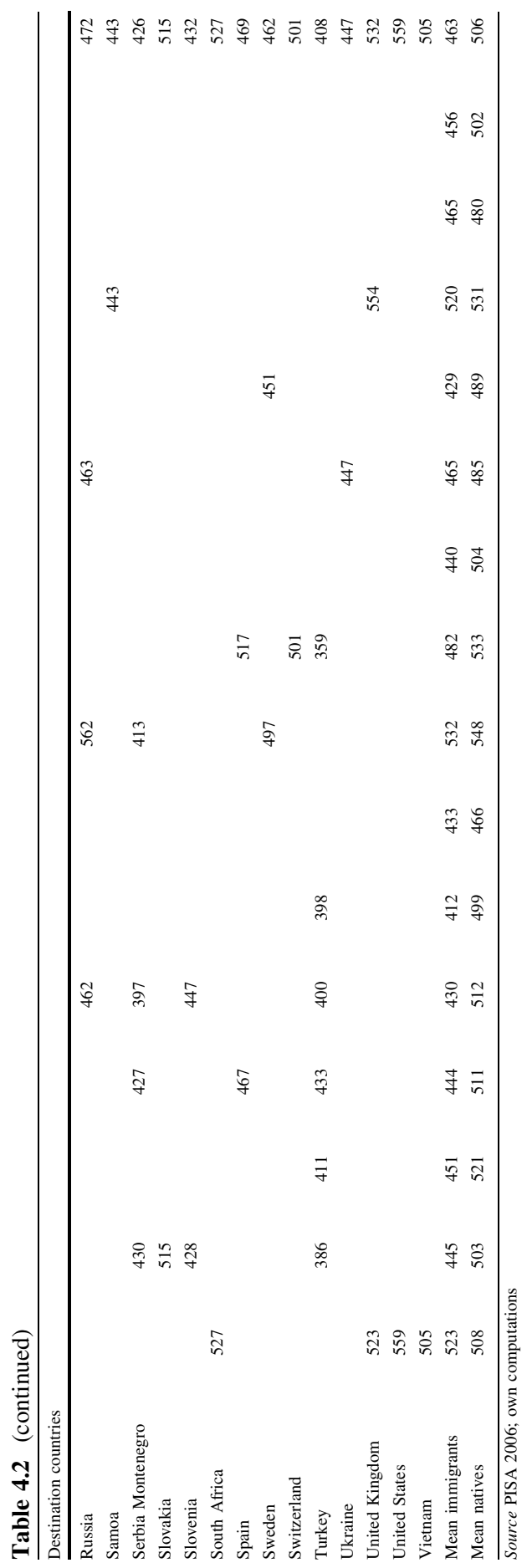




\subsubsection{Characteristics of Individuals}

In line with Rumbaut (2004), we have distinguished generations based on the countries of origin of both parents and child, and the age at which the child immigrated. Second-generation immigrant students are students with at least one parent who was born abroad, while the student was born in the destination country. Students who belong to the first generation were themselves born abroad.

Having one native parent is a dummy variable indicating whether students had one native and one immigrant parent (1) or two immigrant parents ( 0 ; reference category).

Home language is a dummy variable indicating whether the child speaks the country's official language at home (yes 1 ; no 0 ).

Regional origin of students with an immigrant background: Based on earlier analyses of PISA 2003 data (Levels and Dronkers 2008; Levels et al. 2008), we combined the countries of origin in five regions of origin to simplify the presentation of the analysis: Eastern Europe (Albania, Belarus, Bosnia, Croatia, Czech Republic, Estonia, Hungary, Macedonia, Poland, Rumania, Russia, Serbia, and Montenegro, Slovakia, Slovenia, Ukraine); non-Islamic Asia (China, India, Korea, Philippines, Vietnam); Islamic countries (Albania, Bangladesh, Bosnia, Morocco, Pakistan, Turkey); Western OECD countries (Australia, Austria, Belgium, Denmark, France, Germany, Greece, Italy, Netherlands, New Zealand, Portugal, Spain, Sweden, Switzerland, United Kingdom, United States); Sub-Sahara Africa (Cape Verde, Congo, South Africa).

The parental sociocultural status is based on the index of economic, social, and cultural status of the parents (ESCS). It is a composite measure created by the OECD based on the occupational status of the parents (ISEI scale; International Socio-economic Index for Occupational Status; Ganzeboom et al. 1992), the educational level of the parents (ISCED; International Standard Classification of Education, UNESCO 2006), and the presence of any material or cultural resources at the students' homes. ${ }^{7}$ This combination of the parents' occupational status and educational level, together with the resources at home, produces the strongest indicator of the parental environment. We set the average of this index of ESCS of the parents for all destination countries and all students to zero, to ensure that the comparisons for this variable show the result for the average student in a destination country.

Grade. Considering that not all students were at the same level or in the same grade at the time of the PISA survey, we have used the "grade" variable to account for this. The average of this grade variable was set to zero for all destination

\footnotetext{
7 The measure consists of the presence of a desk, a private room, a quiet place to study, a computer, educational software, Internet access, literature or poetry, art, books that may be of use when doing schoolwork, a dictionary, a dishwasher, and the presence of more than 100 books in the house.
} 
countries and all students to ensure that the comparisons for this variable show the result for the student at the average level of 15-year-olds.

Female. Dummy for gender (female 1; male 0).

\subsubsection{Curriculum at the Track-Within-Schools Level}

Vocational. A dummy variable indicates whether a student is currently enrolled in a (pre-) vocational (1) or general (0) type of education (ISCED classification).

Higher secondary. This dummy distinguishes the current track level within secondary education as higher secondary (1) or lower secondary (0).

\subsubsection{Ethnic and Sociocultural Diversity of Schools}

Using the numbers of students from all countries of origin in the trackwithin-school involved, we calculated one minus the Herfindahl index as a measure of ethnic diversity (varying between 0 and 1 ). ${ }^{8}$ Every country of origin here represented a separate ethnic group, including the native students. The index should be interpreted as follows: the value 0 means that there was no ethnic diversity at all in the track, because all students came from the same country of origin. Values that approach 1 represent a very high degree of diversity: all students at that school come from different countries of origin. The Herfindahl index has been criticized for being "color-blind" (Stolle et al. 2008; Voas et al. 2002), which means, for example, that a school with $20 \%$ Turkish students and $80 \%$ native students obtains the same diversity score as a school with $20 \%$ native students and $80 \%$ Turkish students. The specific ethnic share of the track-within-school is therefore also important, and hence we used appropriate indicators (see below).

In a similar way, we calculated the sociocultural diversity of the trackswithin-schools. Using the social class index (ESCS scores) of the parents we divided these parental scores into five categories: the group with the lowest $10 \%$ scores, the 10-30\% group, the 30-70 \% group, the 70-90\% group, and the group with the highest $10 \%$ scores. $^{9}$ Based on these five categories, we calculated the Herfindahl index of sociocultural diversity (varying between 0 and 1 ). ${ }^{10}$ The index should be interpreted as follows: a value of 0 means that there is no diversity,

\footnotetext{
8 The Herfindahl index of ethnic diversity was calculated as follows: $1-$ [(percentage of ethnic group 1$)^{2}+(\text { percentage of ethnic group } 2)^{2}+\cdots+(\text { percentage of ethnic group n })^{2}$ ].

9 The groups are defined as follows: 1) Less than $10 \%$ : ESCS $\leq-1.1$; 2) $10-30 \%$ : $-1.0<$ ESCS $\leq-0.4$; 3) 30-70\%: $-0.3<$ ESCS $\leq 0.6$; 4) 70-90\%: $0.7<$ ESCS $\leq 1.2$; 5) more than $90 \%$ : ESCS $\geq 1.3$.

10 The Herfindahl index of sociocultural diversity was calculated as follows: $1-$ [(percentage of parents from ESCS group 1$)^{2}+(\text { percentage of parents from ESCS group } 2)^{2}+\cdots+($ percentage of parents from ESCS group 5) ${ }^{2}$ ].
} 
because all parents of all students at that particular track-within-school are in the same ESCS category. A value approaching 1 indicates a very high level of diversity, indicating that the students are equally recruited from the five ESCS categories. As this Herfindahl index of sociocultural diversity is "level-blind" and therefore insensitive to the average parental educational level, we have also added the average ESCS of a school to the analysis (see below).

\subsubsection{Ethnic and Sociocultural Average/Share of Track-Within-Schools}

Present students originating from different immigrant regions. As indicated above, the countries of origin were combined into five categories in order to simplify the presentation of the analysis. For each track-within-school, we calculated five indexes: the percentage of students from Eastern Europe, the percentage of students from non-Islamic Asia, the percentage of students from Islamic countries, the percentage of students from Western OECD countries, and the percentage of students from Sub-Sahara Africa. These indexes are the necessary counterparts of the Herfindahl index of ethnic diversity, which after all is "color-blind". Together, these indexes measure the combined effect of ethnic diversity and ethnic share.

Average sociocultural status of the parents. We also calculated the average parental ESCS per track-within-school. This index is the necessary counterpart of the Herfindahl index of sociocultural diversity, which is "level-blind". Together, these indexes measure the combined effect of sociocultural diversity and sociocultural average.

\subsubsection{Characteristics of Schools}

The degree to which schools suffer a shortage of teachers is an index, which indicates to what extent education is hampered by a lack of the following factors: qualified physics teachers, qualified mathematics teachers, qualified language teachers, and qualified teachers for the other subjects. This index is based on answers given by school principals. The average of this index for teacher shortage was set to zero for all destination countries and all students to ensure that the comparisons for this item show the result for the student in a school exhibiting an average shortage of teachers.

Student-staff ratio: the number of students per staff member per school. This index is based on the answers given by the school principals. The average for this ratio was set to zero for all destination countries and all students to ensure that the comparisons for this item show the result for the students in schools with an average student-staff ratio.

School located in (large) city or the countryside. 


\subsubsection{Characteristics of Educational Systems}

Degree of stratification: the educational systems are divided into "highly stratified", "moderately stratified", and "hardly stratified". We define Austria, Germany, Liechtenstein, and Switzerland as countries with highly stratified systems; Belgium, Greece, Luxembourg, and Portugal are countries with moderately stratified systems; and Australia, Latvia, New Zealand, and Scotland are countries with hardly stratified systems. This classification is based on the age when students first must make a choice between different types of education, the number of types of education from which students can choose, and the presence of a more hidden clustering of students based on performance (internal stratification). Although PISA provides this information for all destination countries, in addition we have used information provided by country experts (Schneider 2008; Shavit and Müller 1998; UNESCO 2006). In general, these different sources show a similar pattern. In the highly stratified educational systems, students can choose from at least three types of education at the age of 10 (Austria and Germany), at the age of 11 (Liechtenstein), or at the age of 12 (Switzerland). In the moderately or hardly stratified systems, students cannot choose between different types of education until the age of 15 . We have used two dummy variables to show the degree of stratification. Hardly stratified systems (Australia, Latvia, New Zealand, and Scotland) constitute the reference category.

\subsection{Analysis}

Native students and students with an immigrant background have been analyzed separately, using a multilevel analysis with four levels: students, trackwithin-schools, schools, and countries. The countries of origin of the students with an immigrant background are treated as individual characteristics at the student level to keep the analysis as comparable as possible.

Tables 4.3 and 4.4 show the results for students with an immigrant background and native students, respectively. The structure of the analysis is identical for both populations. The first model shows the effect of both ethnic and sociocultural diversity, and average/share on the students' language skills. In the second model, the individual characteristics of students (including their immigration characteristics) are added, so that the effects of ethnic and sociocultural diversity, and average/share can no longer be distorted by the unequal distribution of students across schools with different populations. In the third model, we add the curriculum that the students are attending. In the fourth model, we added other school characteristics. In both Models 3 and 4, we want to ensure that the effects of ethnic and sociocultural diversity, and average/share have not been caused by the curriculum attended by the students and the schools' resources. 


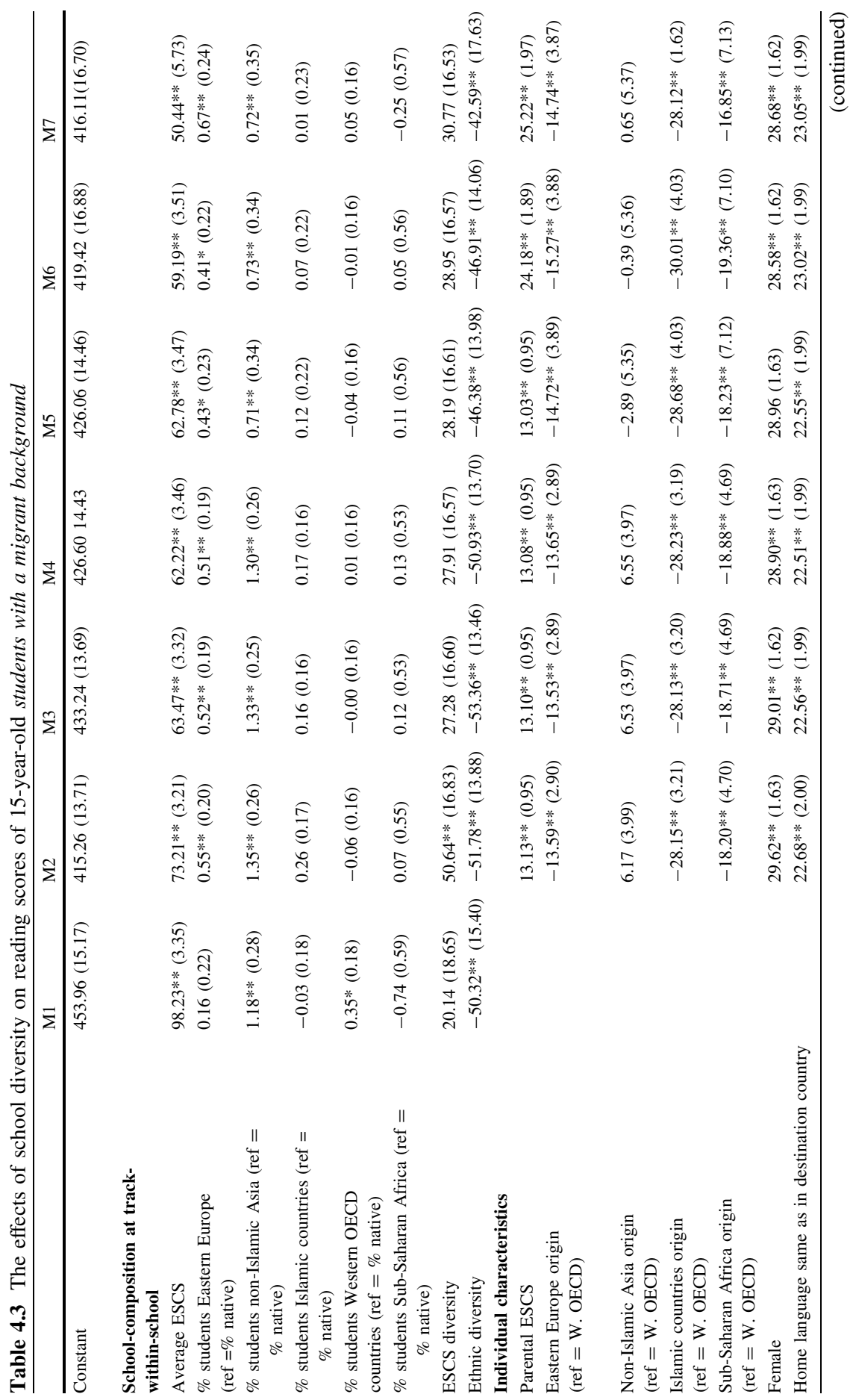




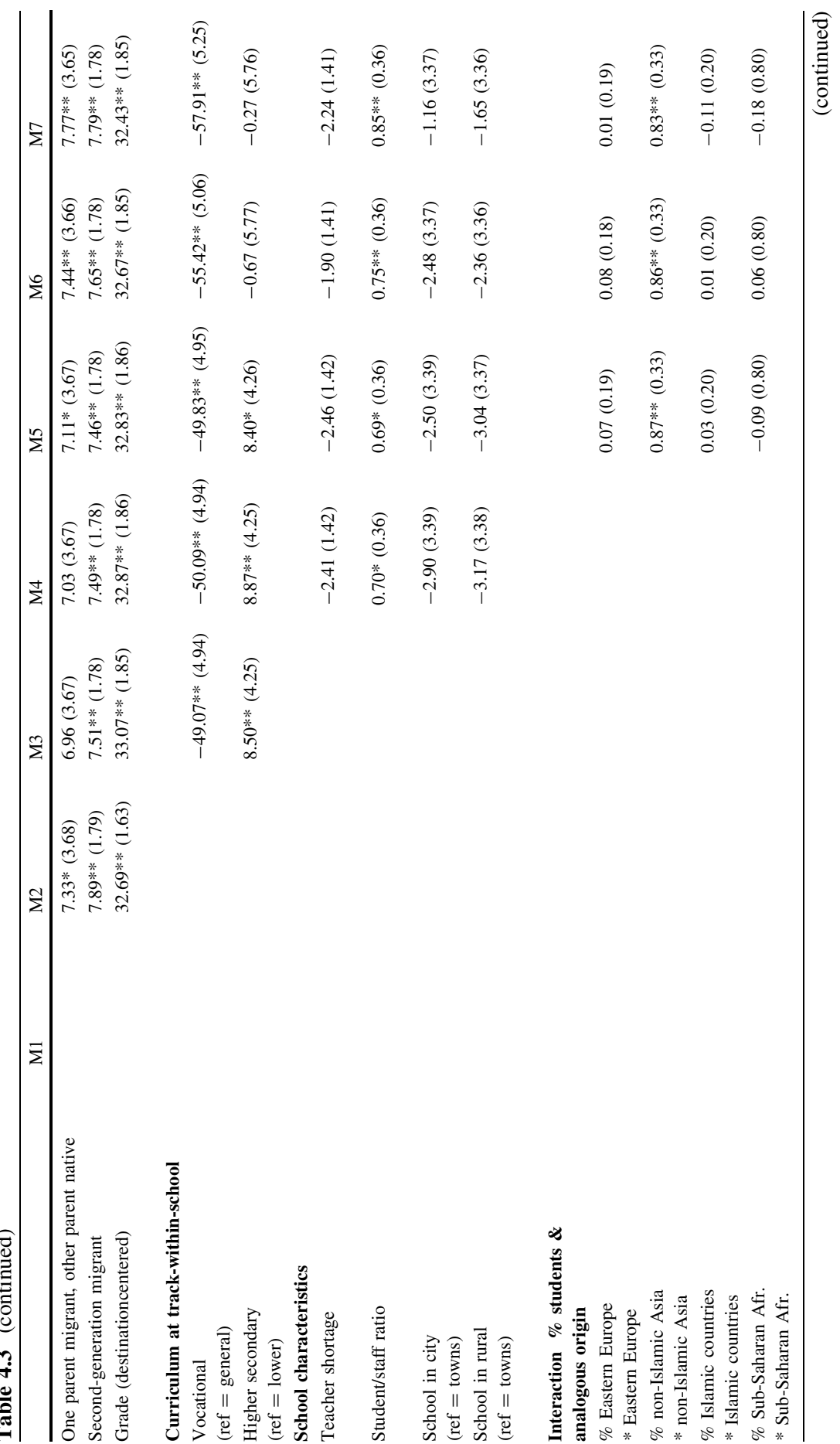




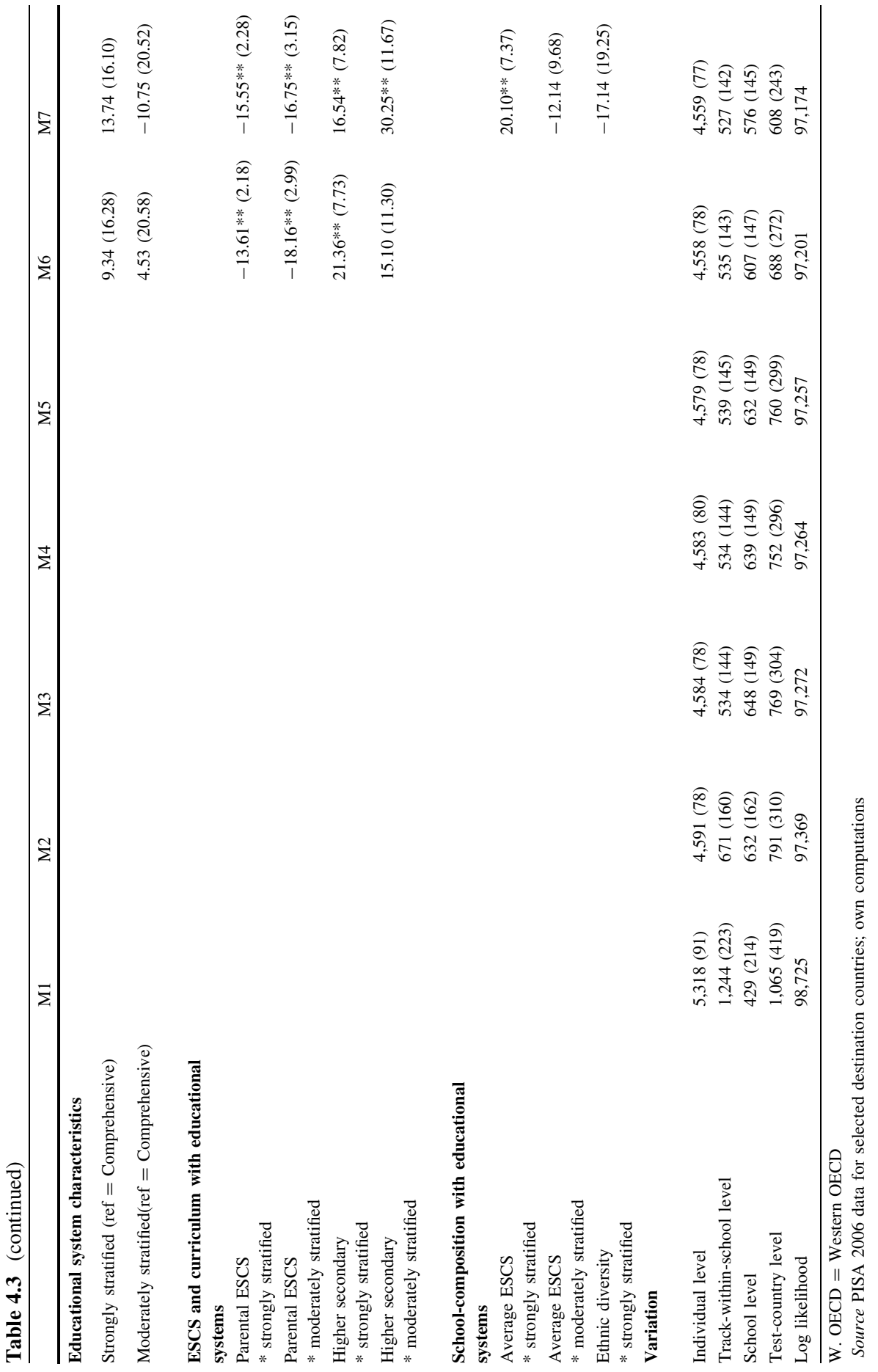




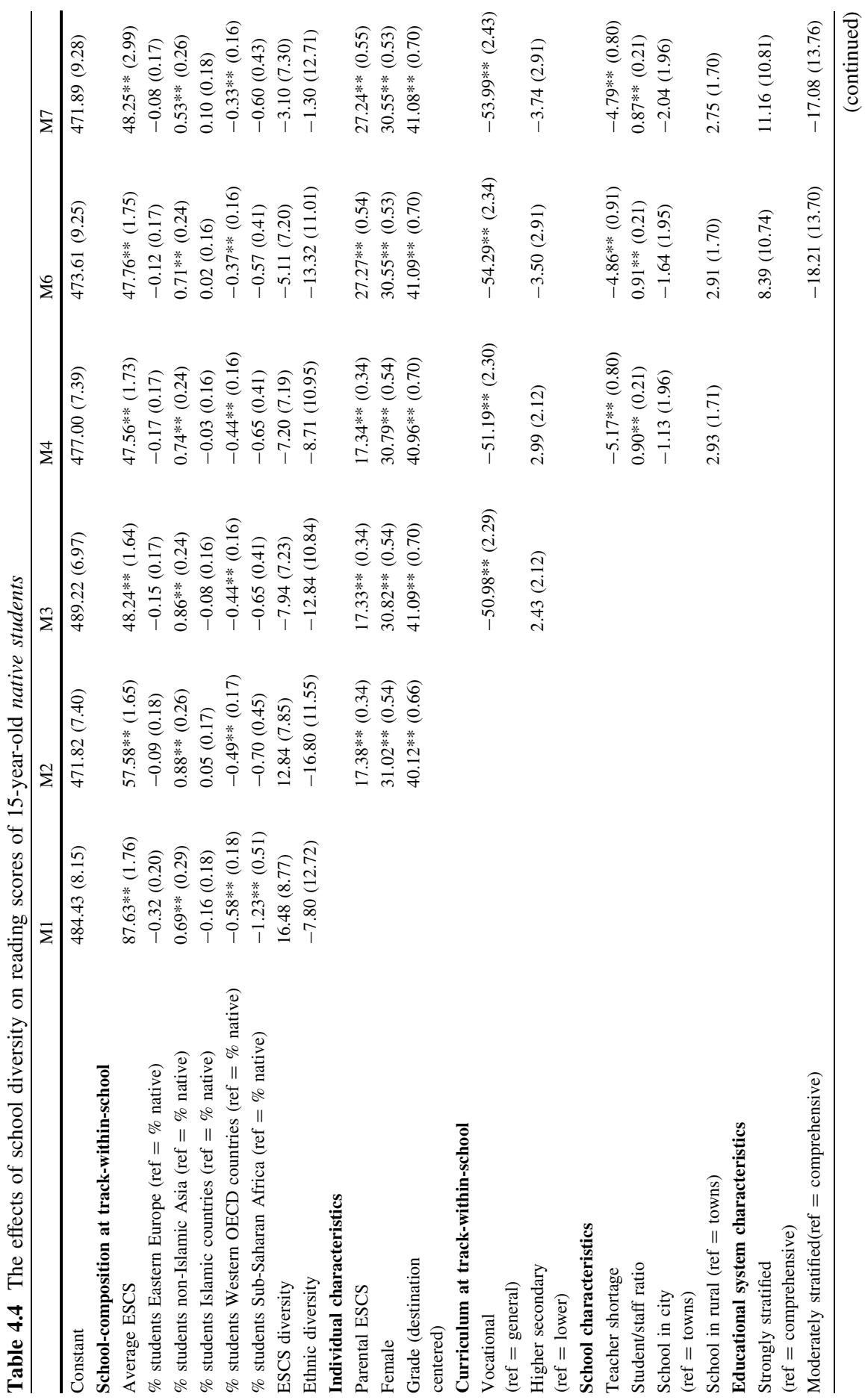




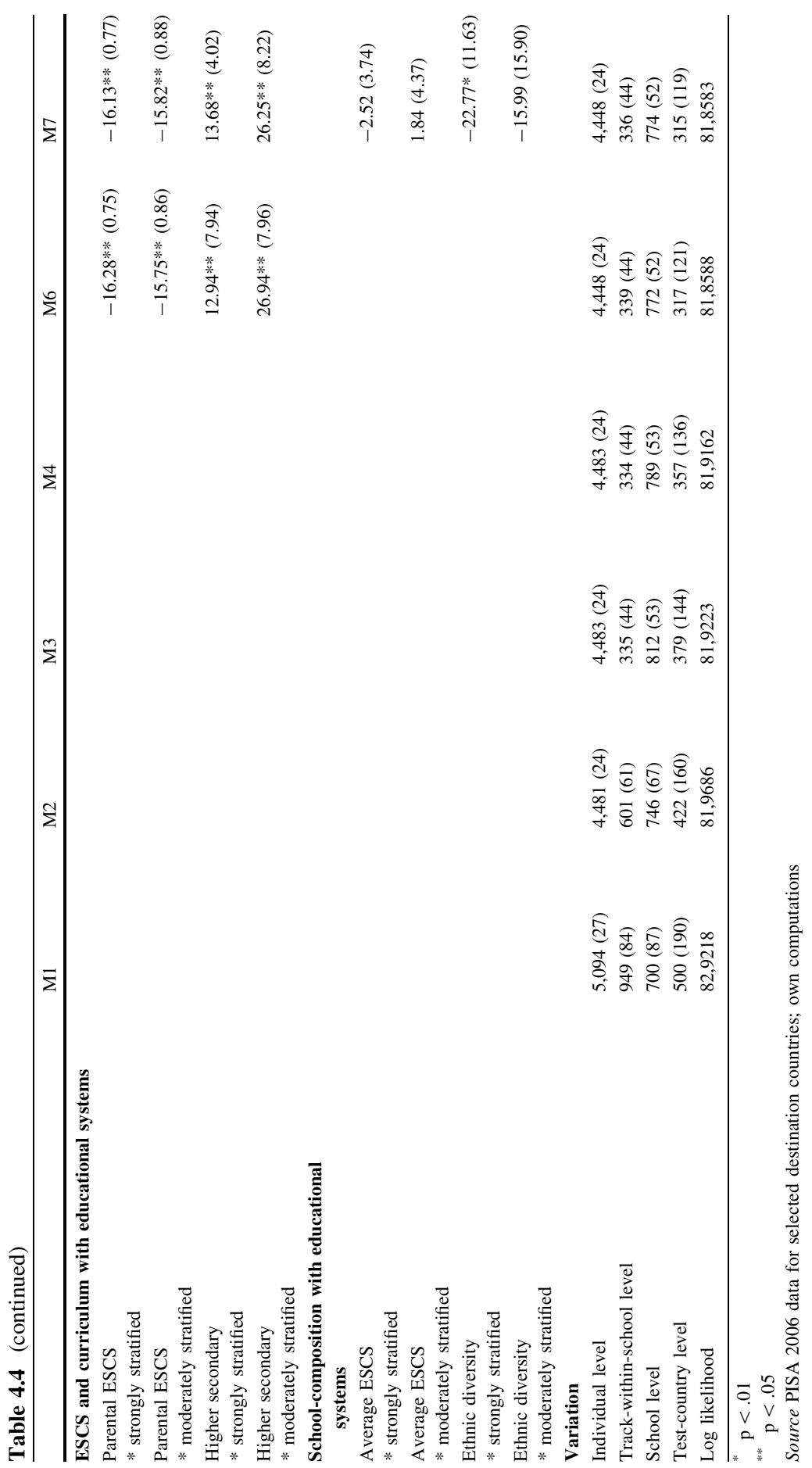


The fifth model (which is only relevant for students with an immigration background) determines whether a particular ethnic share of schools affects the language skills of students with the same ethnic origin. The last two models, 6 and 7 , include the effect of stratification of educational systems in relation to parental ESCS and the curriculum that the students attend (Model 6), and ethnic diversity ${ }^{11}$ and sociocultural average/share of schools (Model 7). The purpose of the last two models is to analyze whether the degree of stratification of educational systems affects the relations between ethnic and sociocultural diversity, and average/share and the language skills. The included effects of stratification of educational systems in relation to parental ECSC and the curriculum in these two models are based on other analyses (Dunne 2010; Dronkers et al. 2011), and are not further discussed here.

\subsection{Research Results}

The main results in relation to the two research questions on diversity and composition are based on Tables 4.3 and 4.4, and in particular on Models 4 and 7. We will not discuss interesting results outside these two research questions (for instance, the effect of parental ESCS on performance in different educational systems) due to a lack of space, but refer to the relevant publications (Dunne 2010; Dronkers et al. 2011).

1. A higher ethnic diversity of schools has a considerably negative effect on the language skills of students with an immigrant background, regardless of the degree of stratification of the educational system in the countries of destination. For native students, a greater ethnic diversity of schools has only a negative effect in highly stratified educational systems. Moreover, on average, students with an immigrant background attend schools with, on average, a more than three times larger ethnic diversity than do native students (Table 4.1) and thus are more hampered by ethnic diversity of school than are native students. These negative effects of ethnic diversity cannot be explained by the other characteristics included in the model.

2. A higher parental ESCS diversity of schools has no significant positive or negative effect on the learning performance of either students with an immigrant background or native students. This nonsignificant effect cannot be explained by the other characteristics included in the model.

3. A higher percentage of students originating from non-Islamic Asian countries increases the learning performance of both native students (5 points more on the language-skills test per $10 \%$ more students from non-Islamic Asian

11 We also run models with the interaction between stratification level of educational system and ESCS diversity. The parameters of these interactions were never significant. Given the emphasis of this chapter, we did not include them in the equation of Model 7. 
countries) and for immigrant students origination outside non-Islamic Asian countries (7 points more on the language-skills test per $10 \%$ more students from non-Islamic Asian countries). The positive effect of a higher percentage of students from non-Islamic Asian countries is even stronger for students from non-Islamic Asian countries: they score 16 points higher on the language-skills test for each $10 \%$ more students from non-Islamic Asian countries. This means that these students from non-Islamic Asian countries can quickly convert their nonsignificant advantage in the language-skills test $(0.65 \text { points })^{12}$ into a significant advantage in educational performance in schools with a high share of students from the same non-Islamic Asian countries, in particular compared with other students with an immigrant background. Analogous positive effects of a higher percentage of students from the same region do not apply to students coming from other regions of origin (see interaction effects). This effect of the percentage of students from non-Islamic Asian countries cannot be explained by the other characteristics included in the model.

4. The language skills of students with an immigrant background are positively affected by the percentage of students from Eastern Europe at their school (7 points for each $10 \%$ more students from Eastern Europe). This effect of the percentage of students from Eastern Europe cannot be explained by the other characteristics included in the model.

5. A higher percentage of students from Western OECD countries decreases the language skills of the native students ( 3 points less on the language-skills test for each $10 \%$ more students from Western OECD countries). The percentages of students from other regions (except that of the non-Islamic Asian countries) have no positive or negative effects on the language skill of the native students. These effects of percentages of various regions cannot be explained by the other characteristics included in the model.

6. The average sociocultural status (ESCS) of the parents has a strong effect on language skills, for both students with an immigrant background (50.4) and native students (48.3). This effect, for native students, is the same across all educational systems, regardless of their level of stratification, and only after controlling for the level of the curriculum (see Dronkers et al. 2011). The effect of average ESCS is even stronger for students with an immigrant background in highly stratified educational systems $(50.44+20.10=70.54)$. Moreover, students with an immigrant background are enrolled primarily in schools in which the average ESCS is $1 / 5$ of a standard deviation lower than for native students (Table 4.1).

7. The substantially lower language skills of students from Islamic countries (28 points $=$ one-third of the standard deviation) cannot be explained based on their individual backgrounds, the attended curriculum, or the characteristics of the school or educational system. None of the other comparable students originating from other regions has such low scores compared with the reference

12 Compared with students from Western OECD countries. 
group of students from Western OECD countries. Students from Sub-Saharan Africa score only 17 points lower, and students originating from Eastern Europe, 15 points lower than students from Western OECD countries, while students originating from non-Islamic Asian countries have the same language skill scores as students from Western OECD countries.

\subsection{Conclusions}

"Diversity in education" is much too wide and inclusive a term to be applied in a meaningful manner. We need a clear conceptual and policy-oriented distinction between diversity and average/share of schools. In addition, ethnic and sociocultural diversity, and average/share should be regarded conceptually as two different dimensions, despite the high correlations between diversity and average/share within countries. Current research and policies on ethnic and sociocultural diversity, and average/share of schools fails to provide this conceptual and policyoriented clarity.

The analyses confirm the strong impact of the average parental sociocultural status on school performance. There are relatively few differences in the effect of the average parental sociocultural status in the different educational systems.

The main contribution of the current analysis is in introducing the diversity concept in this kind of research. The results show that high ethnic diversity of schools hampers to a similar degree the educational performance of students with an immigrant background in all destination countries, regardless of the level of stratification of their educational systems. A high ethnic diversity of schools also hampers the educational performance of native students but only in educational systems with a high degree of stratification. One possible explanation of ethnic diversity's stronger effects for students with an immigrant background is that such students may have fewer resources at home. Therefore, they are in general more vulnerable to experience a decreased effectiveness of learning and teaching resulting from larger ethnic diversity. There is an analogy with the effect of the summer holiday, in which the educational performance of children with few parental resources declines, whereas children with abundant parental resources can maintain the level of their educational performance during the summer holiday (Cooper et al. 1996; Entwisle et al. 1997).

We do not find a similar effect for sociocultural diversity. Higher or lower sociocultural diversity of school neither hampers nor promotes the educational performance of students with an immigrant background or that of native students. For immigrant students, this is only true after controlling for the level of the attended curriculum.

From these findings, we can conclude two things. First, the main characteristic of school populations in the sociocultural dimension is sociocultural average and not sociocultural diversity. Second, a large difference is observed between the effects of ethnic and sociocultural diversity. Ethnic diversity of schools has a 
negative effect on educational performance, but this does not apply to sociocultural diversity at schools. Why not? Is ethnic diversity more difficult to bridge than sociocultural diversity? Does ethnic diversity require more and more costly social capital (more bridging than bonding) than sociocultural diversity (less bridging than bonding)? Does greater ethnic diversity in schools therefore demand more time to bridge the differences, resulting in diminished time for teaching and learning in ethnically diverse schools? If this is the case, is less time required to bridge the differences in socioculturally diverse schools, so that the amount of teaching and learning time is not less in socioculturally diverse schools?

This analysis shows again that making a distinction between the countries of origin is necessary to understand more fully the effects of immigration in education. Our results show that it is very important to include all origin countries in the analyses, not just the problematic ones. Singling out only the problematic groups (e.g. Islam countries), means to close one's eyes to the achievements of successful immigrants from other regions (e.g., non-Islamic Asia), to underestimate the positive effects of certain types of immigration, and to demonstrate less understanding of the causes of integration and assimilation of immigrants in the destination countries. Our results also show that the usual distinction between Western and non-Western immigrants, made by EUROSTAT and other European agencies, fails to do justice to the differences within these broad categories.

For a correct estimation of the effect of ethnic share, the percentage of immigrant students is misleading, because it does not take into account the origin of the immigrant population. As almost all analyses of the effects of school populations only use the percentage of immigrant students (Driessen 2007) and fail to measure diversity, most results are distorted and therefore unreliable (a favorable exception is Westerbeek 1999).

Students from non-Islamic Asia have an advantage when it comes to educational performance, also compared with native students. Other groups profit as well from the presence of this group of immigrant students in schools. The standard explanations for this advantage (working harder for education; authoritarian educational system; the "ideal immigrant") do not stand up empirically from a cross-national perspective (see Dronkers and Heus 2010b). Understanding the case of Asian immigrants is therefore a much greater challenge for European educational research than the traditional European-USA comparison of their educational systems (see also Dronkers 2010a).

Students from Islamic countries have a substantial disadvantage in language scores compared with other immigrant students from other countries of origin, which cannot be explained based on individual socioeconomic backgrounds, school characteristics, or the educational system's characteristics. Multiple explanations may be proposed: discrimination directed towards immigrant children from Islamic countries; negative selection of guest worker programs, in which most guest workers in Europe came from Islamic countries; or values and standards of the current Islam that are less suitable for success in modern societies (honor, unequal gender roles). André et al. (2009) have used data from the European Social Survey (ESS) to show that the degree of subjective feelings of 
discrimination for immigrants in the EU is not greater than for Greek Orthodox or Jewish believers. Dronkers and Heus (2010a) have shown that the negative selection of immigrants from Turkey is not larger than that from non-Islamic guest worker countries (Yugoslavia, Italy, Portugal). Dronkers and Fleischmann (2010) have shown, based on the same ESS data, that second-generation male Muslims in Europe obtain a lower educational level than comparable immigrants espousing different religious beliefs. Moreover, they have shown it is the Islamic faith of individual immigrants that leads to a lower educational level, not the fact of originating from a country with an Islamic majority. These latter results make it important to look for explanations other than discrimination or negative selection to understand the low scores of students from Islamic countries.

Studies and discussions concerning the advantages and disadvantages of educational systems for the level of the educational performance and, for educational inequality, should always include the related school characteristics, because the effects of educational systems manifest themselves mainly through changes in school characteristics and school average/share (Dunne 2010). The risk of perverse effects of well-meant changes in educational systems is therefore great. On the other hand, it is also wrong to state that educational systems have no effect on the level of educational performance and educational inequality.

\subsection{Policy Implications}

Ethnic and sociocultural diversity, and average/share are two conceptually distinct terms, and it is empirically possible to measure their effects separately. Lumping ethnic and sociocultural average/share and diversity of schools together is therefore wrong and misleading, as is the use of the term black school as an excuse by principals for the poor performance of their schools.

There is insufficient empirical support for a forced increase of the ethnic diversity in schools. Bussing ethnic minorities across schools, as has been applied in the USA as a result of civil rights legislation, is therefore counterproductive. In fact, we find strong evidence of the opposite: ethnically homogeneous schools are in a better position to decrease the educational disadvantages of immigrant students from certain countries or origin than ethnically diverse schools. The ethnic homogeneity of Hindu schools or Islamic schools is therefore not a valid argument for closing them with a view to the educational performance of their students (Driessen and Merry 2010; Driessen 2008).

There is also no evidence supporting the forced increase of the sociocultural diversity in schools of secondary education. We find no effect at all of sociocultural diversity. Distributing students from high social status background across all schools is a zero-sum game at best. It simply means that the average performance of schools will become more similar, but the gains of the former low-status schools will be offset by the losses of the former high-status schools. 
Students from Islamic countries have substantially lower educational outcomes that cannot be explained based on their individual socioeconomic backgrounds, school characteristics, or characteristics of the educational system. Suggesting that these differences are all due to the students' socioeconomic backgrounds or the school characteristics or the educational systems in which they are placed does not contribute to improving these students' situation.

It is important to bear in mind educational systems' differing effects on both the level of educational performance and educational inequality among native students and students with an immigrant background. Some groups fare better in highly stratified systems, while others are better off in largely unstratified systems (see Dronkers et al. 2011).

\subsection{Epilogue}

In spite of these research results, one may still advocate for increasing ethnic and sociocultural diversity in schools. However, better educational performance can no longer be used as an argument to support this view. One may feel that ethnically and socioculturally more diverse schools reduce the social distance between ethnic groups and social classes and decrease discrimination, in accordance with intergroup contact theory. Intergroup contact theory was first drawn up by Allport (1954), and later extended by Pettigrew (1998) and others. It states that interpersonal contact between members of the majority group and the minority group contributes to the prevention of negative views on the other group, but only if this interpersonal contact meets certain conditions. The positive result of contact between groups is greatest if five conditions have been met: equal status between groups, shared objectives, cooperation between groups, support by legislation and customs, and the possibility of emerging friendships. Many studies support this prediction (see Pettigrew 1998). In many cases, however, not all conditions have been met. When this occurs, the positive effect of interpersonal contacts is less certain, and forced intergroup contact may even widen the social distance between ethnic groups and increase mutual discrimination. Houtte and Stevens (2009), for example, have found for Flanders that native students in schools with a larger share of students with an immigrant background have a greater number of friends with an immigrant background. Yet Houtte and Stevens did not find this effect for students with an immigrant background: the ethnic share and diversity of school populations did not affect their number of native friends. Neither did they find a relationship between the ethnic share and diversity of Flemish schools, and the students' sense of feeling at home in school.

Nevertheless, even if the policy of increasing ethnic diversity in schools were to reduce the social distance between ethnic groups, this need not automatically be a reason to continue this policy. In that case, a political choice must be made, which is the following: What is more important for our society: less social distance between ethnic groups or better educational performance of immigrant students? 
This is a political question, one that cannot be decided by scientific research, as the answer depends on the standards and values of the citizens. Before they answer this question, though, citizens should know that ethnic diversity brings with it both positive and negative effects. In their choice for better educational performance, the citizen who makes a choice should also remember that the "real and existing" discrimination of highly educated immigrants in the European labor markets (Heath and Cheung 2007; Fleischmann and Dronkers 2008) should be tackled as well. Because education cannot solve the problems of societies; at best, it can merely create the conditions that promote a reduction of those problems.

\section{References}

Allport, G. 1954. The nature of prejudice. Reading: Addison-Wesley.

André, S., J. Dronkers, and F. Fleischmann. 2009. Verschillen in groepsdiscriminatie, zoals waargenomen door immigranten uit verschillende herkomstlanden in veertien lidstaten van de Europese Unie. Mens en Maatschappij 84(4): 448-482.

Coleman, J.S., E.Q. Campbell, C.J. Hobson, J. McPartland, A. Mood, F.D. Weinfield, and R.D. York. 1966. Equality for educational opportunity. Washington: U.S. Government Printing Office.

Cooper, H., B. Nye, K. Charlton, J. Lindsay, and S. Greathouse. 1996. The effects of summer vacation on achievement test scores: A narrative and meta analytic review. Review of Educational Research 66(3): 227-268.

Driessen, G. 2007."Peer group" effecten op onderwijsprestaties.Eeninternationaalreview van effecten, verklaringen en theoretische en methodologischeaspecten. Nijmegen: ITS.

Driessen, G. 2008. De verwachtingen waargemaakt? Tweedecennia islamitische basisscholen. Mens en Maatschappij 83(2): 168-189.

Driessen, G. and Merry, M.S. 2010. Hindoescholen in Nederland. Eenalternatieve route naarintegratie? Migrantenstudies 26(1): 21-40.

Dronkers, J. 2010a. Quality and inequality of education.Cross-national perspectives. Heidelberg: Springer.

Dronkers, J. 2010b. Positieve maar ook negatieve effecten van etnische diversiteit in scholen op onderwijsprestaties? Een empirische toets met internationale PISA-data. Tijdschrift voor Onderwijsrecht en Onderwijsbeleid 6: 483-499.

Dronkers, J. and Fleischmann, F. 2010. The educational attainment of second-generation immigrants from different countries of origin in the EU member-states. In Quality and inequality of education, Cross-national perspectives, ed. Dronkers J, 163-204. Heidelberg: Springer.

Dronkers, J., and M. de Heus. 2010. Negative selectivity of Europe's guest-workers immigration? The educational achievement of children of immigrants compared with the educational achievement of native children in their origin countries. In From information to knowledge; from knowledge to wisdom: Challenges and changes facing higher education in the digital age, ed. E. de Corte, and J. Fenstad, 89-104. London: Portland Press.

Dronkers, J. and Heus, M. de 2010b. The higher educational achievement of Chinese pupils, inside and outside of Asia: The higher transparency of Chinese numbers or a higher value of learning within Chinese culture? Unpublished manuscript (www.eui.eu/Personal/Dronkers/ English/Heus3.pdf).

Dronkers, J. Van der Velden, R., and Dunne, A. 2011. The effects of educational systems, schoolcomposition, track-level, parental background, and immigrants' origins on the achievement of 
15-year-old native and immigrant students. A reanalysis of PISA 2006. ROA Research Memorandum 2011/6.

Dunne, A. 2010. Dividing lines: Examining the relative importance of between- and withinschool differentiation during lower secondary education. Ph.D. dissertation. Florence: European University Institute.

Entwisle, D.R., K.L. Alexander, and L.S. Olson. 1997. Children, schools, and inequality. Boulder: Westview Press.

van Ewijk, R., and P. Sleegers. 2010. The effect of peer socioeconomic status on student achievement: A meta-analysis. Educational Research Review 5(2): 134-150.

Fleischmann, F., and J. Dronkers. 2008. De sociaaleconomische integratie van immigranten in de EU. Een analyse van de effecten van bestemmings-en herkomstlanden op de eerste en tweede generatie. Sociologie 4(1): 2-37.

Fossati, F. 2010. The effect of integration on migrants' school performance. A multilevel estimate. CIS Working Paper 57. Institute of Political Science, University of Zurich.

Ganzeboom, H.B.G., P. de Graaf, D.J. Treiman, and J. De Leeuw. 1992. A standard international socioeconomic index of occupational status. Social Science Research 21: 1-56.

Heath, A.F., and S.Y. Cheung. 2007. Unequal chances. Ethnic minorities in Western labourmarkets. Oxford: Oxford University Press.

de Heus, M., and J. Dronkers. 2010. De onderwijsprestaties van immigrantkinderen in 16 OECDlanden. De invloed van onderwijsstelsels en overige samenlevingskenmerken van zowel herkomst-als bestemmingslanden. Tijdschrift voor Sociologie 31(2): 260-294.

van Houtte, M., and P.A.J. Stevens. 2009. School ethnic composition and students' integration outside and inside schools in Belgium. Sociology of Education 82(3): 217-239.

Lancee, B., and J. Dronkers. 2011. Ethnic, religious, and economic diversity in the neighbourhood: Explaining quality of contact with neighbours, trust in the neighbourhood, and interethnic trust for immigrant and native residents. Journal of Ethnic and Migration Studies 37(4): 597-618.

Levels, M., and J. Dronkers. 2008. Educational performance of native and immigrant children from various countries of origin. Ethnic and Racial Studies 31(8): 1404-1425.

Levels, M., J. Dronkers, and G. Kraaykamp. 2008. Immigrant children's educational achievement in western countries: Origin, destination, and community effects on mathematical performance. American Sociological Review 73(5): 835-853.

Organization for Economic Cooperation and Development 2007. PISA 2006. Science competencies for tomorrow's world. Paris: OECD.

Pettigrew, T.F. 1998. Intergroup contact theory. Annual Review of Psychology 49(1): 5-29.

Putnam, R.D. 2007. E pluribus unum: Diversity and community in the twenty-first century. The (2006) Johan Skytte prize lecture. Scandinavian Political Studies 30(2): 137-174.

Rumbaut, R. 2004. Ages, life stages, and generational cohorts: Decomposing the immigrant first and second generations in the United States. International Immigration Review 38(3): $1160-1205$.

Scheerens, J., and R. Bosker. 1997. The foundations of educational effectiveness. Kidlington: Pergamon.

Schneider, S.L. 2008. The International Standard Classification of Education (ISCED-97). An evaluation of content and criterion validity for 15 European countries. Mannheim: Mannheimer Zentrum für Europäische Sozialforschung.

Shavit, Y., and W. Müller. 1998. From school to work: A comparative study of educational qualifications and occupational destinations. Oxford: Clarendon Press.

Stolle, D., S. Soraka, and R. Johnston. 2008. When does diversity erode trust? Neighbourhood diversity, interpersonal trust, and the mediating effect of social interactions. Political Studies 56(1): 57-75.

Tubergen, F. van 2005. The integration of immigrants in cross-national perspective. Origin, destination, and community effects. Ph.D. dissertation.Universiteit Utrecht.

United Nations Educational, S. and C. O. 2006. International Standard Classification of Education 1997. Paris: UNESCO. 
Voas, D., A. Crockett, and D.V.A. Olson. 2002. Religious pluralism and participation: Why previous research is wrong. American Sociological Review 67(2): 212-230.

Westerbeek, K. 1999. The colours of my classroom. A study into the effects of the ethnic composition of classrooms on the achievement of pupils from different ethnic backgrounds. Ph.D. dissertation. Florence: European University Institute. 